\title{
Whitefly invasion in Imperial Valley costs growers, workers millions in losses
}

\author{
Refugio A. Gonzalez \\ James I. Grieshop \\ $\square$
}

\author{
George E. Goldman \\ Stephen R. Sutter \\ - Eric T. Natwick \\ Tad Funakoshi
}

\author{
a Howard R. Rosenberg \\ Socorro Davila-Garcia
}

\section{Two years of sweetpotato whitefly infestations in Imperial County have resulted in huge losses to growers of melons and cole crops and in high unemployment among farmworkers. The economic impact on the county is analyzed here.}

The sweetpotato whitefly has been a pest in the low desert valleys of Southern California since 1928, and during the 1980s it became a significant transmitter of lettuce infectious yellows virus to iceberg lettuce, melons, and sugarbeets. During fall 1990, large populations of a new strain of the sweetpotato whitefly, Bemisia tabaci (Gennadius), devastated melon, broccoli, cabbage, and cauliflower crops in the Imperial Valley. The new strain, referred to as Biotype- $B$, has caused - and continues to cause - significant crop losses, resulting in great economic hardship to farmers and farmworkers. In February 1992, for example, the Imperial County Agricultural Commissioner's Office estimated whitefly damage of fall and winter 1991-92 crops resulted in losses of approximately $\$ 111$ million. This estimate includes loss of the gross values of crops and their production costs.

Employment data collected and made available by the Imperial County Employment Development Department for 1990, 1991, and January-July 1992 were analyzed to document the economic impact on the county of the whitefly invasion. The information gained should be of value to legislators and other decision makers.

\section{Economic impact indicators}

The number of unemployment insurance (UI) weeks claimed in Imperial County are shown in figure 1; the weeks claimed correspond with the number of Saturdays in a given month. The Employment Development Department (EDD) reports benefits paid to eligible unemployed individuals. In August of both 1990 and 1991, eligible persons from all economic sectors claimed a total of more than 70,000 unemployment insurance weeks. The line in figure 1 illus-

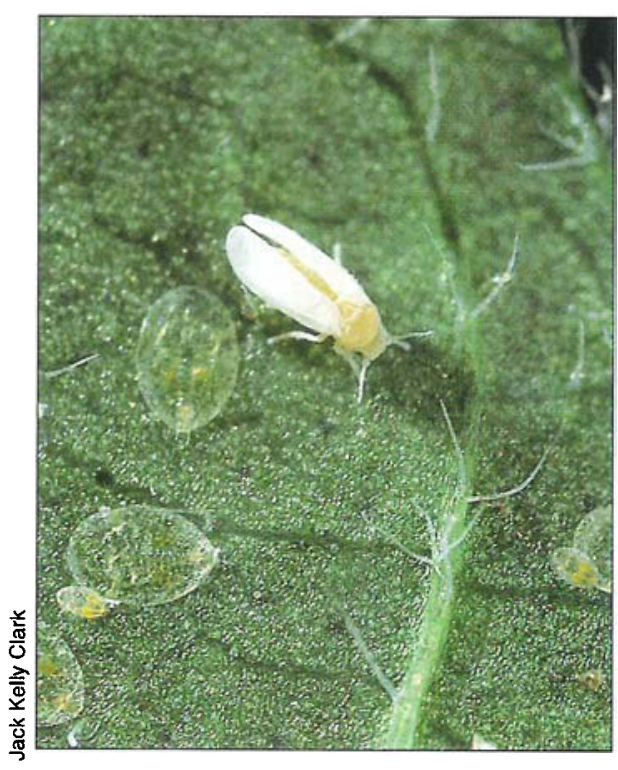

An adult sweetpotato whitefly, here shown on cotton, carries plant diseases from crop to crop oblivious to the grief it brings to farmers and farmworkers, and thus far immune to their efforts at its control.

trating employment in Imperial County in 1992 shows similar seasonal trends at a higher overall level.

Between September 1990 and February 1991 the number of unemployment insurance weeks claimed decreased and remained low. The pattern of unemployment insurance weeks claimed and farmworker employment experience for this time frame coincides with the vegetable crop planting and harvesting calendar in the Imperial Valley (fig. 2). During this time, farmers and farmworkers are preparing for planting - irrigating, thinning, weeding, and harvesting - and businesses that sell fertilizers, feeds, chemicals and other farm-related products are also busy. The result is that correspondingly lower numbers of agriculturerelated insurance claims are filed. The line in figure 3 for 1990-1991 shows that agricultural employment rises and remains high during that period.

From November 1991 through January 1992, whitefly devastation of fall vegetable crops resulted in a $21 \%$ increase in the number of UI weeks claimed, compared with November 1990 through January 1991. EDD reports show that the number of UI weeks claimed from November 1991 through January 1992 totaled 173,283, compared with 136,274 claimed from November 1990 through January 1991. Data in figure I suggest that farmworkers lost jobs and remained unemployed at higher rates in 1992 than in 1990 and 1991 during the period of traditionally high employment, September through March. In addition, the dense clouds of whiteflies feeding on late fall and early winter vegetable crops reportedly delayed crop maturity for 2 to 3 weeks. The result was that the late fall and early winter plantings hit the same harvest dates (late December through January) as the late winter planting.

Even without "hard" numbers - but based on the number of grower inquiries received by Imperial County Farm Advisor Keith Mayberry from vegetable-growing areas - it is safe to assume that farmers in the lower Rio Grande Valley of Texas, southwestern Arizona, California's southern San Joaquin Valley and coastal valleys, and northwest Mexico observed the Imperial Valley's disastrous winter harvest and increased their production of winter vegetables. This action then resulted in a flooded market with consequently low prices paid to farmers. In

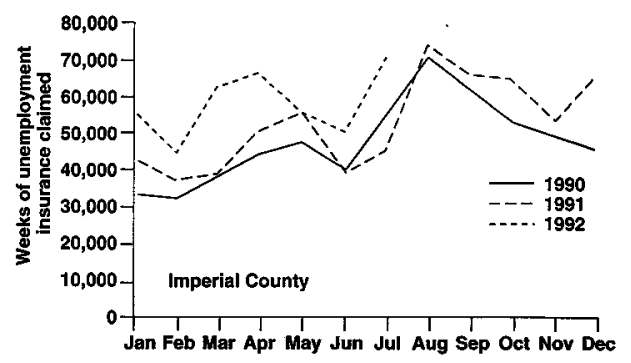

Fig. 1. Number of unemployment insurance weeks claimed in Imperial County over three years. Damage from sweetpotato whitefly Biotype- $B$ is one cause for the higher overall trend in 1992. Source: Employment Development Department, Imperial County. 




Fig. 2. Planting and harvest are labor-intensive activities. This calendar shows that most vegetable crops are planted and harvested from September to February in the Imperial Valley, a period that coincided in 1991-1992 with an increase in unemployment claims (fig. 1) and a decrease in farm employment (fig. 3 ).

turn, when farmers receive poor returns, they usually react by diminishing harvest activities; farmworker unemployment then follows.

Figure 3 shows that, following the scenario described above, employment in Imperial County's agricultural sector dropped drastically and remained low through the first half of 1992. Low agricultural employment, as shown, reflects estimates, since information from quarterly tax reports of agricultural employers is not yet available. Estimates are based on EDD formulas for estimating employment/unemployment in areas that are not part of a standard metropolitan statistical area. Labor-force data are generally updated with a lag time of approximately 1 year. Benchmarking of these data may therefore actually yield higher or lower employment levels. It should be noted that agricultural employment includes all workers in the industry: office and field workers and supervisors, and others engaged in cooling, trucking, distribution, sales, and container operations.

\section{Outlook for 1992-93}

Whitefly populations in Imperial County in August 1992 appear to be 30 days ahead of August 1991, according to the county Agricultural Commissioner. The levels of whitefly infestation in Yuma County, Ari- zona and in the Mexicali Valley of Baja California are also reported higher in 1992 than in 1991 by Leon Moore, retired Cooperative Extension entomologist, University of Arizona, Tucson; Barry Tickes, Cooperative Extension agent, Yuma County; Raul Leon Lopez, research station director in Baja California; and Guillermo Sada, special assistant to the Governor of Baja California. As of late August 1992, officials of the Secretaria De Agricultura $Y$ Recursos Hidraulicos (SARH), the leading federal agricultural department in Mexico, were considering declaring a state of emergency in the Mexicali Valley because of whitefly devastation.

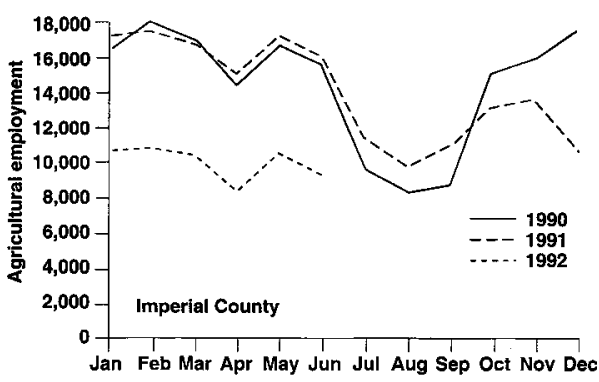

Fig. 3. Agricultural employment in Imperial County over three years. The drop of about 6,000 jobs in 1992 would account for a significant portion of the 10,000 unemployed workers indicated in figure 1. Source: Employment Development Department, Imperial County.
In 1992, Imperial Valley farmers, already under financial stress, are not planting fall cantaloupes or mixed melons, crops that are extremely susceptible to whitefly infestation and damage. According to the Imperial County Agricultural Commissioner's Annual Crop Report for 1991, approximately $95 \%$ of the 1990 cantaloupe and mixed melon crops was lost to whitefly destruction. Furthermore, farmers have delayed planting winter vegetable crops 1 to 2 weeks with the hope that cooler temperatures may reduce whitefly populations.

Decisions made by farmers will impact employment patterns in the Imperial Valley. Because the sectors comprising today's economy are interdependent, changes in any one sector affect all other sectors. The totals of these changes are called multiplier effects. For example, a \$1 million decline in melon production in Imperial county could produce corresponding estimated losses of $\$ 1,265,000$ in local personal income and 42 jobs. These estimates are derived by using the U.S. Forest Service's IMPLAN system for generating county level economic input-output models. Economists across the country use the input-output models produced from this system to estimate the multiplier effects of changes in local economic flows. When farmworkers, for example, lose their jobs, they seek unemployment insurance, general assistance through the county's Department of Social Services, help from other community-based organizations, and employment in nonagricultural sectors.

As this article goes to press, Assembly Bill 2342, authored by Steve Clute (Republican, 68th District), has been passed by the California Legislature and sent to Governor Pete Wilson for his approval. AB 2342 calls for a 26-week extension of unemployment benefits for more than 6,000 farmworkers in both Imperial and Riverside counties.

R. A. Gonzalez is County Cooperative Extension Director, Imperial County; G. E. Goldman is Cooperative Extension Economist, UC Berkeley; E. T. Natwick is Farm Advisor, Imperial County; Howard R. Rosenberg is Cooperative Extension Labor Management Specialist, UC Berkeley; S. R. Sutter is Area Farm Advisor in Fresno, Kings, and Madera counties; T. Funakoshi is the Research Manager of JS/AG Data Group, Employment Development Department, Sacramento; and S. DavilaGarcia is the Research Analyst for the Special Program Data Group, Employment Development Department, Sacramento.

The authors wish to thank Angel Somera, manager of the Imperial County Employment Development Department, for his assistance in this project. 